\title{
PERBEDAAN DAYA HAMBAT ANTISEPTIK ALAMI BAWANG PUTIH (Allium sativum) DENGAN ANTISEPTIK SINTETIK TERHADAP PERTUMBUHAN BIAKAN MURNI BAKTERI Staphylococcus aureus, DAN Escherichia coli
}

\author{
Nurmaningsih \\ * Universitas Nahdlatul Ulama Nusa Tenggara Barat \\ Email : nink_cute86@yahoo.com
}

Penelitian yang bertemakan Bahan Alam ini bertujuan untuk membandingkan kemampuan dari bahan alami dengan bahan kimiawi sintetik dalam memperhambat pertumbuhan dari biakan murni bakteri, sehingga daya antiseptik dari masing-masing bahan tersebut mampu ditentukan kemampuannya dalam mencegah terjadinya infeksi pada tubuh manusia. Bahan alami yang peneliti gunakan dalam adalah bawang putih (Allium sativum). Sedangkan untuk bahan kedua peneliti menggunakan bahan kimia sintetik betadin yang merupakan antiseptik buatan yang sudah teruji kemampuannya dalam menghambat pertumbuhan bakteri baik secara medis atau uji laboratorium. Data yang diperoleh dianalisis dengan cara kualitatif yaitu dengan mengelompokkan diameter zona hambatan bakteri menjadi 3 kategori: 1) Diameter > $12 \mathrm{~mm}$ termasuk kategori Sensitif. 2) Diameter 4-12 mm termasuk dalam kategori Intermediet. 3) Diameter $<4 \mathrm{~mm}$ termasuk kategori Resisten. Hasil penelitian membuktikan bahwa terdapat perbedaan daya hambat antiseptik alami bawang putih Allium sativum dengan antiseptik sintetik terhadap pertumbuhan biakan murni bakteri Staphylococcus aureusn dan Escherichia coli

\section{Kata Kunci: Daya Hambat, Antiseptik Alami, Antiseptik Sintetik, Pertumbuhan Biakan Murni Bakteri}

\section{PENDAHULUAN}

Indonesia

sudah

mulai

membudidayakan lebih dari 940 jenis spesies dari flora sebagai tanaman obat, (Syamsul Hidayat, 2005: 7-8). Salah satu dari tanaman obat yang biasa digunakan adalah bawang putih (Alium sativum). Tumbuhan ini dalam masyarakat dipercayai memiliki kemampuan untuk mencegah terjadinya infeksi pada bagian luka.

Bawang putih memiliki kandungankandungan tertentu sehingga mampu menghambat pertumbuhan mikroba, antara lain: 1). Air, protein dan karbohidrat. 2). Vitamin B-Kompleks dan Vitamin C. 3). Mineral kalsium, fosfor magnesium dan kalium. Zat-zat aktif: a) Allicin, senyawa yang dikatakan menurunkan kolesterol darah. b) Skordinin, memberi bau yang kurang sedap pada bawang putih, tetapi senyawa ini berkhasiat sebagai antiseptik. c) Alliil, memberi bau yang khas bawang putih dan juga sebagai antiseptik. d) Diallyl sulfida dan propyl allyl sulfida, kedua senyawa ini bersifat trombolitik atau penghancur gumpalan darah, (Abduh: 2010).
Dari hasil penelitian yang telah dilaksanakan oleh Irmudita Ari Ramdanti, (2008) menunjukan bahwa Allium sativum Linn memiliki aktivitas antibakteri terhadap $E$ coli, yaitu sebagai pembunuh pertumbuhan bakteri (bakterisid). Penelitian Safithri, (2004) menunjukkan bahwa ekstrak air dan etanol bawang putih dapat menghambat pertumbuhan bakteri Streptococcus agalactie, S. aureus, dan E. coli.

Terkait dengan hal tersebut, kita sering melihat dalam keseharian kita, banyak orangorang khususnya anak-anak yang terkena penyakit berekelanjutan dari bekas luka baisa, dimana pada kondisi seperti ini kegiatankegiatan patogenis yang disebabkan oleh adanya kegiatan pertumbuhan dari mikroorganisme di dalam luka tersebut, kemudian terus berkembang sehingga akan terjadi infeksi.

Infeksi merupakan proses masuknya mikroorganisme sebagai penumpang (parasit) dan mengadakan hubungan dengan inang (host), bila parasit tersebut sanggup mengadakan penetrasi atau melalui tanggul pertahanan inang dan hidup di dalamnya, 
(Koes Irianto, 2007: 111). Agar tidak terjadi infeksi berlanjut, maka diperlukan pengobatan untuk menghindari berkembangnya mokroorganisme tersebut di bagian tubuh dengan memberikan antiseptik apabila itu di bagian luar tubuh atau antibiotic apabila terjadinya infeksi di bagian dalam tubuh.

Penelitian yang bertemakan Bahan Alam ini bertujuan untuk membandingkan kemampuan dari bahan alami dengan bahan kimiawi sintetik dalam memperhambat pertumbuhan dari biakan murni bakteri, sehingga daya antiseptik dari masing-masing bahan tersebut mampu ditentukan kemampuannya dalam mencegah terjadinya infeksi pada tubuh manusia. Bahan alami yang peneliti gunakan dalam adalah bawang putih (Allium sativum). Sedangkan untuk bahan kedua peneliti menggunakan bahan kimia sintetik betadin yang merupakan antiseptik buatan yang sudah teruji kemampuannya dalam menghambat pertumbuhan bakteri baik secara medis atau uji laboratorium.

Oleh karena itu, berdasarkan uraian di atas penelitian ini berjudul Perbedaan Daya Hambat Antiseptik Alami Bawang Putih (Allium Sativum) Dengan Antiseptik Sintetik Terhadap Pertumbuhan Biakan Murni Bakteri Staphylococcus aureus, dan Escherichia coli.

\section{METODE PENELITIAN}

Penelitian ini termasuk jenis penelitian eksperimen. Desain penelitian yang digunakan adalah desain penelitian kuantitatif, yang meneliti perbandingkan daya antiseptik alami bawang putih allium sativum dengan antiseptik sintetik terhadap pertumbuhan biakan murni bakteri Staphylococcus aureus, dan Escherichia coli. Penelitian dilakukan di Laboratorium Mikrobiologi dan Botani FKIP Universitas Mataram pada bulan Januari 2019. Sampel dalam penelitian ini terdiri atas antiseptik yang diteliti daya resistensinya terhadap biakan murni bakteri, yakni antiseptik alami Alium sativum dan antiseptik sintetik (betadin dan dettol). Jadi sampel penelitian ini dapat kita tentukan yakni satu suing dari satu rumpun bawang putih, satu botol betadin dari satu kotak yang berisi 12 botol dan satu botol detol cair.
Variabel penelitian ini terdiri dari variabel Antiseptik dan variabel biologi. Variabel antiseptik meliputi antiseptik alami yakni bawang putih dan antiseptik sintetik yakni betadin, sedangkan variabel biologi terdiri dari pertumbuhan biakan murni bakteri Staphylococcus aureus, dan Escherichia coli. Penelitian ini dilaksanakan melalui beberapa tahapan yaitu: tahap persiapan, tahap pembuatan medium, dan tahap pelaksanaan dan Pengambilan data dilakukan selama dua kali pengulangan pada masing-masing sampel yang terdapat dalam medium padatan.

Pengukuran aktivitas antibakteri dilakukan dengan mengukur diameter zona hambatan yang terbentuk. Pengukuran dengan menggunakan jangka sorong dan dilaporkan dalam kategori sensitif, intermediet, atau resisten berdasarkan standar pengukuran yang ditetapkan. Perlakuan dilakukan dengan pengulangan sebanyak 2 kali. Data yang diperoleh akan dianalisis dengan cara kualitatif yaitu dengan mengelompokkan diameter zona hambatan bakteri menjadi 3 kategori:

1. Diameter > $12 \mathrm{~mm}$ termasuk kategori Sensitif

2. Diameter $4-12 \mathrm{~mm}$ termasuk dalam kategori Intermediet

3. Diameter $<4 \mathrm{~mm}$ termasuk kategori Resisten

(Mukherjee, K.L.,1988 dalam Rustiningsih, 2010).

\section{HASIL DAN PEMBAHASAN}

Tabel 4.1: Hasil pengamatan diameter zona hambat Antiseptik Alami Bawang Putih (Allium sativum) Dengan Antiseptik Sintetik Terhadap Pertumbuhan Biakan Murni Bakteri Staphylococcus aureus, dan Escherichia coli.

\begin{tabular}{|c|c|c|c|c|c|c|c|c|c|c|c|c|}
\hline \multirow{3}{*}{$\begin{array}{c}\text { Antisepti } \\
\mathrm{k}\end{array}$} & \multicolumn{6}{|c|}{ Eschericia coli } & \multicolumn{6}{|c|}{ Staphylococcus aureus } \\
\hline & \multicolumn{3}{|c|}{$50 \%(\mathrm{~mm})$} & \multicolumn{3}{|c|}{$90 \%(\mathrm{~mm})$} & \multicolumn{3}{|c|}{$50 \%(\mathrm{~mm})$} & \multicolumn{3}{|c|}{$90 \%(\mathrm{~mm})$} \\
\hline & I & II & $\begin{array}{l}\text { rata- } \\
\text { rata }\end{array}$ & I & II & $\begin{array}{l}\text { rata } \\
\text { rata }\end{array}$ & I & II & $\begin{array}{l}\text { rata } \\
\text { rata }\end{array}$ & I & II & $\begin{array}{l}\text { rata } \\
\text { rata }\end{array}$ \\
\hline Bawang & 23,8 & 24,8 & 24,3 & 25 & 11,0 & 18,0 & 15,9 & 9,9 & 12,9 & 10,92 & 10,4 & 10,66 \\
\hline Putih & 6 & 4 & 5 & & 8 & 4 & 2 & 4 & 3 & & & \\
\hline Dettol & \multicolumn{6}{|c|}{19,9} & \multirow{2}{*}{\multicolumn{6}{|c|}{$\begin{array}{c}\text { Utk bakteri ini tidak ada zona } \\
\text { hambat yg terbentuk }\end{array}$}} \\
\hline Betadin & \multicolumn{6}{|c|}{25,92} & & & & & & \\
\hline
\end{tabular}

$*$ diameter cakram disk $=5 \mathrm{~mm}$ 
Tabel 4.2: kategori diameter zona hambat Antiseptik Alami Bawang Putih (Allium sativum) Dengan Antiseptik Sintetik Terhadap Pertumbuhan Biakan Murni Bakteri Staphylococcus aureus, dan Escherichia coli.

\begin{tabular}{|l|c|c|c|c|}
\hline \multirow{2}{*}{ Bakteri } & \multicolumn{2}{|c|}{ Diameter Zona Hambat (mm) } \\
\cline { 2 - 5 } & \multicolumn{2}{|c|}{$\begin{array}{c}\text { Antiseptik } \\
\text { Alami } \\
\text { Bawang Putih }\end{array}$} & \multicolumn{2}{c|}{$\begin{array}{c}\text { Antiseptik } \\
\text { Sintetik }\end{array}$} \\
\cline { 2 - 5 } & $50 \%$ & $90 \%$ & Betadin & Dettol \\
\hline Eschericia coli & 24,35 & 18,04 & 25,92 & 19,9 \\
\hline Kategori & $\mathrm{S}$ & $\mathrm{S}$ & $\mathrm{S}$ & $\mathrm{S}$ \\
\hline $\begin{array}{l}\text { Staphylococcus } \\
\text { aureus }\end{array}$ & 12,93 & 10,66 & \multicolumn{2}{c|}{$\begin{array}{c}\text { Tidak ada zona } \\
\text { hambat yang } \\
\text { terbentuk }\end{array}$} \\
\hline Kategori & $\mathrm{S}$ & $\mathrm{I}$ & \multicolumn{3}{|c}{} \\
\hline
\end{tabular}

Keterangan:

$$
\begin{aligned}
& S=\text { Sensitif } \\
& I=\text { Intermediet }
\end{aligned}
$$

\section{Pembahasan}

Dari tabel hasil pengamatan diameter zona hambat antiseptik alami bawang putih (Allium sativum) dengan antiseptik sintetik terhadap pertumbuhan biakan murni bakteri Staphylococcus aureus, dan Escherichia coli di atas dapat dijelaskan bahwa zona hambat yang terbentuk menunjukkan aktivitas yang berbeda-beda terhadap bakteri uji. Sensitivitas bakteri uji terhadap antiseptik alami bawang putih (Allium sativum) dengan antiseptik sintetik dapat dilihat dari zona hambat yang terbentuk, dimana pada zona tersebut tidak ditumbuhi kuman di sekitar cakram disk pada medium setelah diinkubasi selama 24 jam dengan 2 kali pengulangan.

Untuk menentukan zona hambat yang terbentuk, pada praktikum ini digunakan metode difusi disk. Interpretasi hasil pengujian difusi disk dapat dilihat dari dua alternatif. Pertama ialah apabila di sekitar paper disk terdapat zona (daerah) bening tanpa pertumbuhan bakteri; hal ini dinyatakan positif, berarti obat tradisional yang diuji mempunyai daya antimikroba. Alternatif kedua ialah apabila di sekitar paper disk tidak terdapat zona bening yang bebas dari pertumbuhan bakteri; dinyatakan negatif yang berarti obat tradisional yang diuji tersebut tidak mempunyai daya antimikroba (Pudjarwoto, 1992).

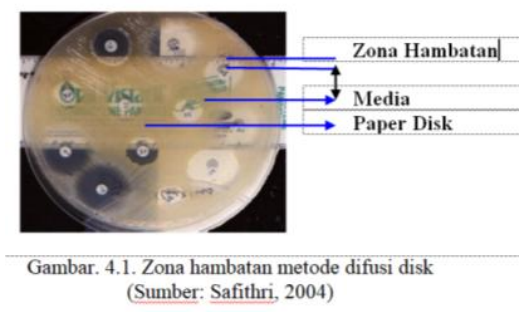

Ekstrak bawang putih pada konsentrasi $50 \%$ dan $90 \%$ pada tabel 4.2 di atas, mampu memberikan hambatan dengan diameter yang berbeda-beda pada bakteri klinik yang diujikan. Hambatan ini dilihat dari zona bening yang terbentuk disekitar cakram disk yang telah ditetesi ekstrak bawang putih pada media yang telah ditanami bakteri dan kemudian diinkubasi selama 24 jam. Perbandingan ekstrak bawang putih konsentrasi 50\%, 90\%, dettol dan betadin memiliki kategori yang sensitif terhadap bakteri Escherichia coli. Ini dapat dilihat bahwa zona hambat yang terbentuk memiliki diameter diatas $12 \mathrm{~mm}$.

Hal ini didukung oleh pendapat Shankar dan Prasad 1998 dalam Safithri bahwa bawang putih mengadung zink yang mempunyai kegunaan penting yaitu sebagai antioksidan, melindungi sel dari pengaruh kerusakan oksidatif yang dihasilkan selama aktivasi imun. selain itu bawang putih mengandung senyawa skordinin, alisin dan allil. Skordinin merupakan golongan antiseptik yang banyak dimanfaatkan dalam ilmu farmasi, (Stephen C. Edberg, 1986: 28). Senyawa skordinin merupakan antiseptik semisintetik yang banyak ditemukan dalam tumbuhan bawangbawangan dan juga merupakan antiseptik alamiah dari bawang-bawangan.

Skordinin berperan sebagai enzim pertumbuhan dalam proses germinasi (pembentukan tunas) dan pengeluaran bawang putih. Selain itu, skordinin juga diyakini dapat memberikan daya tahan tubuh (stamina) dan perkembangan tubuh. Hal ini disebabkan karena kemampuan bawang putih dalam bergabung dengan protein dan menguraikannya, sehingga protein tersebut mudah dicerna oleh tubuh.

Selain kandungan skordinin, bawang putih (Allium sativum) juga mengandung zat yang diduga berperan memberi aroma bawang putih yang khas yaitu Alisin. Alisin 
mengandung sulfur dengan struktur tidak jenuh dan dalam beberapa detik saja terurai menjadi senyawa dialil-disulfida. Di dalam tubuh, alisin merusak protein yang terdapat pada dinding bakteri, sehingga mikroorganisme terutama bakteri akan menjadi mati. Alisin merupakan zat aktif yang mempunyai daya antibiotika sangat ampuh.

Zona hambat bawang putih $50 \%$ pada bakteri E. coli lebih besar dari konsentrasi $90 \%$ yaitu 24,35 mendekati zona hambat pada betadin, sedangkan pada bakteri Staphylococcus aureus zona hambat bawang putih lebih kecil dibanding pada $E$. coli. Nilainilai zona hambat maupun transmisi yang berbeda pada masing-masing konsentrasi dapat diakibatkan oleh banyak faktor dan keadaan yang mempengaruhi efek antimikrobial (Pelczar \& Chan, 1981 dalam Hadiroseyani, 2005).

Salah satu factor yang menyebabkan hal tersebut adalah karena zat aktif pada bawang putih sulit untuk menembus dinding sel bakteri $S$. aureus yang merupakan bakteri gram positif. Hal ini didukung oleh pendapat Kamaluddin, 2001 dalam Safithri: 2004 yang menyatakan bahwa bakteri Gram positif disusun oleh lapisan peptidoglikan yang terletak di luar membran plasma, sebanyak 40 lembar atau 50\% dari komposisi dinding sel. Zat aktif yang dimaksud adalah skordinin, dimana senyawa ini mampu menghambat rantai silang peptidoglikan pada dinding sel bakteri. Akan tetapi pada keadaan ini, daya hambat skordinin pada bakteri $S$. aureus tidak bekerja secara maksimal.

Zat aktif yang ada bawang putih salah satunya yaitu minyak atsiri yang mengandung senyawa fenol yang mampu mendenaturasi protein dan menyebabkan kematian bakteri. Menurut Parwata dan Dewi (2008) minyak atsiri yang aktif sebagai antibakteri pada umumnya mengandung gugus fungsi hidroksil $(\mathrm{OH})$ dan karbonil. Turunan fenol berinteraksi dengan sel bakteri melalui proses adsorpsi yang melibatkan ikatan hidrogen. Pada kadar rendah terbentuk kompleks protein fenol dengan ikatan yang lemah dan segera mengalami peruraian, diikuti penetrasi fenol ke dalam sel dan menyebabkan presipitasi serta denaturasi protein. Pada kadar tinggi fenol menyebabkan koagulasi protein dan sel membran mengalami lisis.

Kandungan minyak atsiri pada bawang putih seperti yang telah disebutkan di atas dapat menghambat pertumbuhan bakteri gram negative yang memiliki dinding peptidoglikan tipis akan tetapi memiliki zat antitoksik yang disebut dengan LPS (lipopolisakarida) yang juga tersusun oleh protein. Selain itu kandungan alisin yang terdapat pada bawang putih juga berperan dalam mendegradasi protein pada dinding sel bakteri gram negative.

Di dalam tubuh, alisin merusak protein yang terdapat pada dinding bakteri, sehingga mikroorganisme terutama bakteri akan menjadi mati. Daya antiseptic bawang putih lebih sensitive terhadap bawang putih karena alisin juga dapat bekerja sebagai antibiotik , sesuai dengan pendapat Purwaningsih (2005) bahwa alisin merupakan zat aktif yang mempunyai daya antibiotik yang cukup ampuh. Itulah mengapa zona hambat yang terbentuk pada bakteri E. coli lebih tinggi daripada bakteri S. Aureus

Zona hambat untuk kedua antiseptic sintetik betadin dan dettol pada bakteri $S$. Aureus tidak terbentuk, ini kemungkinan disebabkan karena banyak factor, salah satunya adalah kadar povidon iodine yang terkandung pada betadin belum sesuai sehingga zona bening tidak terbentuk. Hal ini sesuai dengan pendapat Ganiswara: 1995 dalam Safithri: 2004 yang menyatakan bahwa povidon-iodine bersifat bakteriostatik dengan kadar $640 \mu \mathrm{g} / \mathrm{ml}$ dan bersifat bakterisid pada kadar $960 \mu \mathrm{g} / \mathrm{ml}$.

Pada dettol, zona hambat untuk bakteri $S$. Aureus tidak terbentuk kemungkinan disebabkan karena kandungan kloroheksilenol yang terdapat pada dettol memiliki aktivitas antibakteri yang rendah, sesuai dengan pendapat Fevero 1985 dalam Syaifudin 2005, bahawa kloroheksilenol memecahkan mikroorganisme dengan memecah dinding sel. Hal ini merupakan penghapus kuman yang beraktivitas rendah.

Seperti yang telah disebutkan di atas, banyak factor yang mempengaruhi terbentuknya zona hambat pada bakteri. Berdasarkan Sabir, 2002 dalam Safithri: 2004, diameter zona hambat dipengaruhi oleh toksisitas bahan 
uji, kemampuan difusi bahan uji pada media, interaksi antar komponen medium dan lingkungan in vitro. Banyak faktor yang dapat mempengaruhi aktivitas suatu zat antibakteri, maka secara langsung akan mempengaruhi besar diameter zona hambat.

\section{KESIMPULAN}

Berdasarkan hasil pengamatan dan pembahasan di atas dapat disimpulkan sebagai berikut:

1. Terdapat perbedaan daya hambat antiseptik alami bawang putih Allium sativum dengan antiseptik sintetik terhadap pertumbuhan biakan murni bakteri Staphylococcus aureusn dan Escherichia coli

2. Besarnya perbedaan daya hambat antiseptik alami bawang putih Allium sativum dengan antiseptik sintetik terhadap pertumbuhan biakan murni bakteri Staphylococcus aureusn dan Escherichia coli ditunjukkan dengan diameter zona hambat yang terbentuk yaitu:

a. Terhadap bakteri $E$. colli menunjukkan bahwa antiseptic alami bawang putih (Allium sativum) pada konsentrasi 50\% dan 90\%, serta antiseptic sintetik betadin dan dettol menghasilkan zona hambat dengan kategori sensitif.

b. Terhadap bakteri Staphylococcus aureus, antiseptic alami bawang putih (Allium sativum) pada konsentrasi 50\% menghasilkan zona hambat dengan kategori sensitif, sedangkan pada konsentrasi $90 \%$ menghasilkan zona hambat dengan kategori intermediet. Pada antiseptic sintetik betadin dan dettol, tidak terbentuk zona hambat, hal tersebut bisa diakibatkan oleh banyak factor seperti yang telah di bahas pada bab sebelumnya.

\section{DAFTAR PUSTAKA}

Bibiana, 1994. Analisis Mikroba di Laboratorium. Jakarta: PT Raja Grapindo Persada.

David Roser, 2002. Bawang Putih untuk Kesehatan. Jakarta: PT Bumi Aksara.

Evika Sandi Savitri, 2008. Rahasia Tumbuhan Berkhasiat Obat Perspektif Islam. Malang: UIN-Malang Press.
Hadiroseyani, Hafifuddin, M. Alifuddin, dan H. Supriyadi, 2008. Potensi Daun Kirinyuh (Chromolaena odorata) Untuk Pengobatan Penyakit Cacar Pada Ikan Gurame (Osphronemus gouramy) Yang Disebabkan Aeromonas hydrophilla. Jurusan Budidaya Perairan, Fakultas Perikanan dan Ilmu Kelautan, Institut Pertanian Bogor

Iyam Siti Syamsiah, 2003. Khasiat dan Manfaat Bawang Putih Raja Antibiotik Alami. Jakarta: PT AgroMedia Pustaka.

J.M Gibson, M.D, 1996. Mikrobiologi Dan Patologi Moderen Untuk Perawat. Jakarta: Penerbit Buku Kedokteran ECG

Koes Irianto, 2007. Mikrobiologi Menguak Dunia Mikroorganisme Jilid 1 Bandung: CV. Yrama Widya.

Michael J. Pelczar, 2008. Dasar-dasaar Mikrobiologi Jilid 1. Jakarta: UI-Press.

Parwata, O. A. dan F.S. Dewi. 2008. Isolasi dan Uji Aktivitas Antibakteri Minyak Atsiri dari Rimpang Lengkuas (Alpinia galanga l.). Jurnal Kimia, Denpasar.

Pudjarwoto T., H. Cyrus. Simanjuntak, dan P.N. Indah., 1992. Daya Antimikroba Obat Tradisional Diare terhadap Beberapa Jenis Bakteri Enteropatogen. Badan Penelitian dan Pengembangan Kesehatan Departemen Kesehatan RJ., Jakarta

Purwaningsih, E. 2005. Manfaat Bawang Putih. Ganesa Ecsat, Bandung.

Safithri, M. 2004. Aktivitas Antibakteri Bawang Putih (Alium sativum) terhadap Bakteri Mastitis Subklinis secara Invintro dan Invivo pada Ambing Tikus Putih (Rattus novergicus) (Tesis). Program Pascasarjana, Institut Pertanian Bogor, Bogor.

Sidqi Anwar, 2008. Aktifitas Alcohol 70\%, Povidon Iodine 10\% Dan Kasa Kering Steril Dalam Pencegahan Infeksi Pada Perawatan Tali Pusat Di Ruang Neonatologi Bagian Ilmu Kesehatan Anak RSU Zainoel Abidin Banda Aceh. Jurnal Dinamika Edisi Mei-Agustus.

Syaifudin, 2005. Panduan Pencegahan Infeksi untuk Fasilitas Pelayanan Kesehatan denghan Sumber Daya 
Terbatas. Jakarta : Yayasan Bina

Pustaka Sarwono Prawirohardjo

Syamsul Hidayat, 2005. Ramuan Tradisional

Ala 12 Etnis Indonesia. Jakarta: Penebar Suwadaya.

Stephen C. Edberg, 1986. Antibiotika dan Infeksi Edisi 2. Jakarta: Penerbit Buku Kedoktran.

Ramadanti, Irmudita Ari, 2008. Uji Aktivitas Antibakteri Ekstrak Bawang Putih (Allium Sativum Linn) Terhadap Bakteri Escherichia Coli In Vitro. Skripsi. Semarang: Universitas Diponegoro Semarang.

Rustiningsih. 2010. Uji Aktivitas Tanaman Kelor (Moringa oleifera Lamk.) Terhadap Pertumbuhan Bakteri Isolat Klinik. Skripsi S1 Program Studi Biologi, Universitas Mataram 